\title{
166. Experimentelle und klinische Untersuchungen der gewebeständigen Plasminogenaktivatoren nach Polytrauma
}

\author{
Sylvia Denk, Ingrid Wriedt-Lübbe, G. Schlag und G. Blümel
}

Inst. f. Experimentelle Chirurgie d. Technischen Universität München (Dir.: Prof. Dr. G. Blümel), Forschungsabt. II d. AUVA im Lorenz-Böhler-Krankenhaus Wien (Ärztl. Dr.: Prof. Dr. J. Böhler)

\section{Experimental and Clinical Studies of the Tissue-Bound Plasminogen Activators in the Posttraumatic Period}

\begin{abstract}
Summary. The presence of the tissue-bound plasminogen activators during the posttraumatic period was shown by fibrinolysis-autography in experimental studies in rats and clinically in patients. After application of the natural proteinase inhibitor Aprotinin the tissue-bound activator was not reduced, whereas the application of the synthetic fibrinolysis inhibitor trans-Amcha decreased the activator content in the lungs of rats. Plasminogen values were in the normal range. The presence of plasminogen and its substrate, the tissue-bound activator, is an adequate condition for a normal fibrinolysis.
\end{abstract}

Key words: Polytrauma - Plasminogen activator - Fibrinolysis.

Zusammenfassung. Das Vorhandensein des gewebeständigen Plasminogenaktivators nach Polytrauma wurde experimentell bei Ratten und klinisch bei Patienten fibrinolyseautographisch nachgewiesen. Nach Gabe des natürlichen Proteinaseninhibitors Aprotinin war der gewebeständige Aktivator unvermindert vorhanden, während eine Applikation des synthetischen Fibrinolyseinhibitors trans-Amcha den Aktivatorgehalt in den Rattenlungen reduzierte. Der Plasminogenspiegel der Patienten war normal und gewährleistet zusammen mit dem Gewebeaktivator die Voraussetzung für eine ungestörte Fibrinolyse nach Polytrauma.

Schlïsselwörter: Polytrauma - Plasminogenaktivator - Fibrinolyse.

\section{Rectumcarcinom, Exstirpation oder Resektion?}

\author{
W. Schellerer und B. Husemann \\ Chirurgische Univ.-Klinik Erlangen
}

\section{Carcinoma of the Rectum: Abdominoperineal Excision or Anterior Resection?}

Summary. In 1975 the authors treated 120 cases of rectal cancer by abdominoperineal excision resection. Tumors situated less than $6 \mathrm{~cm}$ from the anal verge should be treated by excision of the rectum. The Erlanger magnetic device is implanted to achieve a continent colostomy. 